\title{
AC 2009-723: K-12 SCHOOL COUNSELORS: A PILOT STUDY OF SUPPORT NEEDS FOR ADVISING STUDENTS ABOUT ENGINEERING
}

Macon Beck, Purdue University

Heidi Diefes-Dux, Purdue Universtiy

Teri Reed-Rhoads, Purdue University

Teri Reed-Rhoads is an Associate Professor in the School of Engineering Education at Purdue University. 


\title{
K-12 School Counselors: A Pilot Study of Support Needs for Advising Students about Engineering
}

\begin{abstract}
School counselors provide an opportunity to encourage students with diverse backgrounds to enter engineering. The disparity between school counselors' available time and students' desire for career advising creates the need for high quality and effective career advising materials and support for school counselors. Little research has been conducted around the issue of what is needed to support school counselors in advising students about engineering careers. This pilot study was designed to answer the following questions, "What are school counselors' understanding of engineering" and "What is the self-reported need for and support desired by professional school counselors to aid their work with academic and career development related to students and engineering?" An online survey instrument was developed to collect information from school counselors about (1) their perceptions of engineering, (2) the perceived barriers to advising students about engineering careers, (3) engineering topics about which they would like to advise their students, (4) desired time and location for professional development workshops, and (5) their interest in collaborating with other teachers on engineering lessons. The survey was made available through a school counselors' list-serve. Results indicate that lack of time and knowledge about engineering is a barrier for school counselors when advising students about engineering careers. In addition, workshops should not be scheduled on Saturdays, after school, or during the summer. Recommendations for future research are provided.
\end{abstract}

\section{Introduction}

What motivates counselors to attend a workshop on engineering? When is a good time to have a workshop for counselors? What is the best way to access counselors? These questions were raised after a Purdue University recruitment team planned and held a workshop for school counselors that no one attended.

School counselors provide an opportunity to encourage students, particularly those with diverse backgrounds, to enter engineering. However, according to one source, school counselors spend the majority of their time scheduling, testing, and shuffling papers; this leaves an estimated $20 \%$ of their time to advise students about their future career choices ${ }^{1}$. Students, on the other hand, have become less certain of their choice of major, and each year consistently more than $40 \%$ indicate that they need help with their educational and occupational plans ${ }^{2}$. The disparity between school counselors' time and students' desire for career advising creates the need for high quality and effective career advising materials and support for school counselors. Little research has been conducted around the issue of what is needed to support school counselors in advising students about engineering careers. The purpose of this paper is to start the conversation and provide insight into what types of support and materials are needed and desired by school counselors to support them as they advise students about engineering pathways. 


\section{A. Literature Review}

\section{Engineering}

America is the place where dreams happen, as evident by the creativity, discovery, and innovation of the American workforce. These workforce attributes contribute to the United States being a leader in science and engineering fields. The U.S.'s leadership in these fields has been held secure by the ample supply of a well-educated workforce ${ }^{3}$. However, for the past several years, the Trends in International Mathematics and Science Study (TIMSS) has revealed that America's youth lag behind those of other nations such as Japan, England, Singapore, and Chinese Taipei. ${ }^{4,5}$ In addition, the National Assessment of Educational Progress (NAEP) revealed that $39 \%$ of the United States twelfth graders performed below the proficient level on the 2007 math test, while the 2005 science test scores showed no improvement since 2000 when $82 \%$ of twelfth graders performed below the proficient level ${ }^{6,7}$. Science, technology, engineering, and mathematics (STEM) fields are expected to increase in the number of needed positions during the 2000-2010 period, while graduates with engineering degrees over this same time period are expected to remain stable ${ }^{2}$. The number of students graduating with an engineering degree is not the only concern, but the diversity of these graduates is also a concern. There is a documented lack of diversity and shortage of students entering the STEM fields $8,9,10,11$.

The projected workforce needs necessitate a substantial increase in the number of well-prepared students, particularly female and under-represented minority students, recruited into engineering pathways. To nurture a broader interest in engineering, there have been several efforts made to create K-12 programs directed toward all students, often with emphasis on females and minorities. In addition, programs have been designed to help teachers incorporate engineering into their classrooms ${ }^{12}$. School counselors, on the other hand, have been a neglected resource that needs attention and support to be able to encourage and advise all students about the engineering profession ${ }^{2,12}$. After all, when it is time to guide students toward a future career and education pathway, it is school counselors and parents who encourage (and discourage) students to attend (or not attend) college and take (or not take) preparatory coursework.

\section{Counselor Job Responsibilities}

There is an identified need to work with and provide support for school counselors as they advise students about the engineering profession. However, there is limited research on school counselors advising with engineering. What is the nature of the support from and relationship with the engineering community needed by school counselors as they advise students about careers?

Today's school counselors need to be informed about the kinds of occupational and educational opportunities emerging in our knowledge-based society so that they can guide high school students toward these opportunities and help them identify the best-suited postsecondary education, while helping parents look objectively at possible alternatives to the four-year college degree ${ }^{13}$. School counselors report that the majority of their time is spent on paper work, testing, and scheduling ${ }^{14}$. Counselors battle an internal desire to spend more of their time 
individually counseling, group counseling, and attending professional development activities with having to attend to practical school needs for testing and routine paperwork ${ }^{14}$. This leaves roughly $20 \%$ of their time for career counseling and even less time for helping students with personal growth and development ${ }^{1}$. This time is spent, to varying degrees, on activities ranging from career days to job shadowing. In 2002, the most common guidance activities offered at public high schools included: use of college catalogs, individual counseling sessions, use of computerized and non-computerized career information sources, and testing and interpreting tests results for career planning purposes ${ }^{1}$. School counselors also have little time for professional development, and they do not make the time if they do not see an immediate need. In 2004, counselors reported spending a half-day or less on professional development activities per year ${ }^{1}$. There is a great need to help school counselors' find time for education and career counseling and related professional development as it is evident that high school students are becoming less certain of their choice of major and need help deciding their educational and occupational plans ${ }^{2}$.

\section{B. Purpose}

The purpose of this pilot study was to determine what types of support school counselors need. It also involves the exploration of school counselors' perceptions of engineering. Specifically, this study is guided by the following research questions:

- "What are school counselors' perceptions of engineering?"

- "What is the self-reported need for and support desired by professional school counselors to aid their work with academic and career development related to students and engineering?"

\section{Method}

This study followed a cross-sectional survey design with quantitative and qualitative questions $^{15}$. This method allowed us to reach our intended audience in an inexpensive and efficient manner. We were able to canvas a variety of school counselors' perceptions about engineering and identify resources available to them about the engineering field.

\section{A. Participants}

The participants consisted of Indiana school counselors. Recruitment of the participants was done through an email solicitation sent to the Counselortalk listserve, which is a confidential list administered by the Indiana School Counselor Association (ISCA). It is the best known method for reaching the target population for this study. As to the participants' STEM preparation, $34.7 \%$ took college courses in science and $34.7 \%$ took college math courses, while only $16.7 \%$ had any college coursework in technology and none had college course work in engineering.

\section{B. Survey Instrument}

An online survey instrument was developed to collect information from school counselors in Indiana about their perceptions of engineering, preparation for and adequacy in advising students about engineering careers, barriers to advising students about engineering careers, and their needs regarding advising students on engineering careers. The thirty-seven item survey 
was created in SurveyMonkey and constructed to take no more than twenty minutes. The items were grouped by the following categories: perceptions of engineering, perceived barriers to advising students about engineering careers, engineering topics about which school counselors would like to advise their students, desired time and location for professional development workshops, and the potential for collaborating with other teachers, and educational data. There were thirty-four 4-point ( $1=$ strongly disagree, $2=$ disagree, $3=$ =agree, and $4=$ strongly agree) Likert-type items; twenty of these were based on the teacher survey developed and validated by Arizona State University. The survey titled, "K-12 Teachers' Perceptions of Design, Engineering, and Technology" was developed for the purpose of learning about elementary, middle, and high school teachers' perceptions of engineers and their familiarity with teaching design, engineering, and technology (DET) ${ }^{16}$. Three open-ended questions were also included to gain more insight into barriers to advising students about engineering and desired resources.

\section{Data Collection}

A link to the anonymous online survey instrument was emailed on April 1, 2008 to the members of the Counsleortalk list-serv. The survey was available through May 1, 2008. Sixty-five surveys were started and fifty-two were completed, which gives an $80 \%$ completion rate. The total number of Indiana school counselors who subscribe to Counselortalk was unable to be determined. Each question had between 50-52 responses. All respondent data is included in the analysis.

\section{Data Analysis}

For Likert-type items, descriptive statistics, (i.e. median, average, and percent agreement) were computed. The median and average did not reveal many differences. The percent agreement allowed us to see the grouping of responses more clearly.

For the open-ended questions, open coding was used to identify recurring words or themes that captured each participant's perceptions about engineering ${ }^{17}$. The codes were then grouped into major themes. The coder was an outreach coordinator for a K-12 engineering education research center and a doctoral student in educational technology.

\section{Results and Discussion}

\section{A. School Counselors' Perceptions of Engineering}

The results for items 1-12 are shown in Table 1. The results indicated that counselors believe that DET has positive consequences for society (Item 12) and engineers earn good money (Item 5 ) and do well in math (Item 3) and science (Item 7). There was less agreement on whether engineers work well with other people (Item 1) and have good verbal skills (Item 2). School counselors agree to a greater extent that most people feel that males can do well in DET careers (Item 10) as compared to females (Item 9) or minorities (Item 11), but this may or may not be a reflection of what school counselors feel. It is not clear whether counselors believe that DET should be integrated into the K-12 curriculum (Item 8). These results are similar to those found for K-12 teachers ${ }^{16}$. This leads us to believe that school counselors and K-12 teachers have 
similar perceptions of engineering. Therefore, the same content that is used in engineering teacher professional development workshops to mitigate misconceptions may be useful in school counselor professional development.

Table 1. School Counselors' Perceptions of Engineering.

\begin{tabular}{|l|l|c|c|c|c|c|}
\hline $\begin{array}{l}\text { Item } \\
\text { No. }\end{array}$ & $\begin{array}{l}\text { Statement } \\
\text { (Number of Responses) }\end{array}$ & $\begin{array}{l}\text { Strongly } \\
\text { Disagree }\end{array}$ & Disagree & Agree & $\begin{array}{c}\text { Strongly } \\
\text { Agree }\end{array}$ & $\begin{array}{c}\text { Average/ } \\
\text { Median }\end{array}$ \\
\hline 1 & $\begin{array}{l}\text { A typical engineer works well } \\
\text { with people. (n=52) }\end{array}$ & $0 \%(0)$ & $15.4 \%(8)$ & $78.8 \%(41)$ & $5.8 \%(3)$ & $2.9 / 3$ \\
\hline 2 & $\begin{array}{l}\text { A typical engineer has good } \\
\text { verbal skills. (n=52) }\end{array}$ & $0 \%(0)$ & $15.4 \%(8)$ & $71.2 \%(37)$ & $13.5 \%(7)$ & $3.0 / 3$ \\
\hline 3 & $\begin{array}{l}\text { A typical engineer has good } \\
\text { math skills. (n=52) }\end{array}$ & $0 \%(0)$ & $0 \%(0)$ & $9.6 \%(5)$ & $90.4 \%(47)$ & $3.9 / 4$ \\
\hline 4 & $\begin{array}{l}\text { A typical engineer has good } \\
\text { writing skills. (n=51) }\end{array}$ & $0 \%(0)$ & $15.7(8)$ & $68.6 \%(35)$ & $15.7 \%(8)$ & $3.0 / 3$ \\
\hline 5 & $\begin{array}{l}\text { A typical engineer does not earn } \\
\text { good money. (n=52) }\end{array}$ & $61.5 \%(32)$ & $34.6 \%(18)$ & $1.9 \%(1)$ & $1.9 \%(1)$ & $1.5 / 1$ \\
\hline 6 & $\begin{array}{l}\text { A typical engineer likes to fix } \\
\text { things. (n=50) }\end{array}$ & $0 \%(0)$ & $14.0(7)$ & $66.0 \%(33)$ & $20.0 \%(10)$ & $2.9 / 3$ \\
\hline 7 & $\begin{array}{l}\text { A typical engineer does well in } \\
\text { science. (n=50) }\end{array}$ & $0 \%(0)$ & $0 \%(0)$ & $48.0 \%(24)$ & $52.0 \%(26)$ & $3.5 / 4$ \\
\hline 8 & $\begin{array}{l}\text { I believe (DET) should be } \\
\text { integrated into the K-12 } \\
\text { curriculum. (n=52) }\end{array}$ & $1.9 \%(1)$ & $15.4 \%(8)$ & $59.6 \%(31)$ & $23.1 \%(12)$ & $3.0 / 3$ \\
\hline 9 & $\begin{array}{l}\text { Most people feel that female } \\
\text { students can do well in DET } \\
\text { courses. (n=52) }\end{array}$ & $0 \%(0)$ & $28.8 \%(15)$ & $61.5 \%(32)$ & $9.6 \%(5)$ & $2.8 / 3$ \\
\hline 10 & $\begin{array}{l}\text { Most people feel that male } \\
\text { students can do well in DET } \\
\text { courses. (n=52) }\end{array}$ & $0 \%(0)$ & $1.9 \%(1)$ & $63.5 \%(33)$ & $34.6 \%(18)$ & $3.3 / 3$ \\
\hline 11 & $\begin{array}{l}\text { Most people feel that minority } \\
\text { students (African American, } \\
\text { Hispanic / Latino, and American } \\
\text { Indian) can do well in DET } \\
\text { courses. (n=52) }\end{array}$ & $0 \%(0)$ & $32.7 \%(17)$ & $55.8 \%(29)$ & $11.5 \%(6)$ & $2.8 / 3$ \\
\hline 12 & $\begin{array}{l}\text { Design/Engineering/Technology } \\
\text { has positive consequences for } \\
\text { society. (n=52) }\end{array}$ & $0 \%(0)$ & $1.9 \%(1)$ & $38.5 \%(20)$ & $59.6 \%(31)$ & $3.6 / 4$ \\
\hline
\end{tabular}

\section{B. Barriers to Advising Students about Engineering Careers}

Table 2 shows the results for items 13-20. There is evidence that a large fraction of these school counselors feel they do not adequately advise students interested in DET (47.1\% disagree or strongly disagree, Item 14), and are not doing all they should to advise students about DET careers (53.8\% agree or strongly agree, Item 15$)$. To a lesser extent, they disagree or strongly disagree that they are prepared to advise students about DET careers (34.6\%, Item 13), These school counselors agree or strongly agree that limited time for them to learn about DET (80.4\%, Item 16), a lack of time to advise students about DET careers (74.5\%, Item 17), a lack of available training (63.5\%, Item 18), and a lack of personal knowledge about DET careers (55.7\%) act as barriers to advising students about DET careers. Only $21.6 \%$ of these school counselors agree or strongly agree that a lack of administration support acts as a barrier to advising students about DET careers. 
Table 2. Barriers to Advising Students about Engineering Careers

\begin{tabular}{|l|l|c|c|c|c|c|}
\hline $\begin{array}{l}\text { Item } \\
\text { No. }\end{array}$ & $\begin{array}{l}\text { Statement } \\
\text { (Number of Responses) }\end{array}$ & $\begin{array}{l}\text { Strongly } \\
\text { Disagree }\end{array}$ & Disagree & Agree & $\begin{array}{c}\text { Strongly } \\
\text { Agree }\end{array}$ & $\begin{array}{c}\text { Average/ } \\
\text { Median }\end{array}$ \\
\hline 13 & $\begin{array}{l}\text { I am prepared to advise my } \\
\text { students in DET careers. (n=52) }\end{array}$ & $1.9 \%(1)$ & $32.7 \%(17)$ & $55.8 \%(29)$ & $9.6 \%(5)$ & $2.7 / 3$ \\
\hline 14 & $\begin{array}{l}\text { I adequately advise all my } \\
\text { students interested in DET } \\
\text { careers. (n=51) }\end{array}$ & $2.0 \%(1)$ & $45.1 \%(23)$ & $45.1 \%(23)$ & $7.8 \%(4)$ & $2.6 / 3$ \\
\hline 15 & $\begin{array}{l}\text { I am not doing all that I should } \\
\text { be in advising my students } \\
\text { about DET careers. (n=52) }\end{array}$ & $9.6 \%(5)$ & $36.5 \%(19)$ & $50.0 \%(26)$ & $3.8 \%(2)$ & $2.5 / 3$ \\
\hline 16 & $\begin{array}{l}\text { The limited time for counselors } \\
\text { to learn about DET acts as a } \\
\text { barrier for advising students } \\
\text { about DET careers. (n=51) }\end{array}$ & $2.0 \%(1)$ & $17.6 \%(9)$ & $70.6 \%(36)$ & $9.8 \%(5)$ & $2.9 / 3$ \\
\hline 17 & $\begin{array}{l}\text { The limited time available to } \\
\text { advise students about DET } \\
\text { careers acts as barrier for } \\
\text { advising students about DET } \\
\text { careers. (n=51) }\end{array}$ & $5.9 \%(3)$ & $19.6 \%(10)$ & $66.7 \%(34)$ & $7.8 \%(4)$ & $2.8 / 3$ \\
\hline 18 & $\begin{array}{l}\text { My lack of knowledge about } \\
\text { DET careers acts as a barrier for } \\
\text { advising students about DET } \\
\text { careers. (n=52) }\end{array}$ & $5.8 \%(3)$ & $38.5 \%(20)$ & $51.9 \%(27)$ & $3.8 \%(2)$ & $2.5 / 3$ \\
\hline 19 & $\begin{array}{l}\text { The lack of available training } \\
\text { acts as a barrier for advising } \\
\text { students about DET careers. } \\
\text { (n=52) }\end{array}$ & $3.8 \%(2)$ & $32.7 \%(17)$ & $55.8 \%(29)$ & $7.7 \%(4)$ & $2.7 / 3$ \\
\hline $\begin{array}{l}\text { The lack of administration } \\
\text { support acts as a barrier for } \\
\text { advising students about DET } \\
\text { careers. (n=51) }\end{array}$ & $11.8 \%(6)$ & $66.7 \%(34)$ & $19.6 \%(10)$ & $2.0 \%(1)$ & $2.1 / 2$ \\
\hline
\end{tabular}

Question 21 asked, "What are the barriers you experience that prevent you from advising students about DET careers?" The coded responses to these questions, shown in Table 3, support the results in Table 2. Lack of knowledge about DET careers and lack of time were prominent themes.

Question 22 asked, "What other barriers are there that you know of in advising students about DET careers?" Interestingly students knowledge (or lack of knowledge) about DET careers appears as a barrier (Table 4).

Two primary barriers were identified across items 13-22. The primary barrier is time - time to learn about DET careers and time to advise students about DET careers. School counselors have expressed that there is currently not enough time to meet with all their students. The lack of time to meet with their students matches what is found in the current literature ${ }^{1,14}$. The second barrier is lack of knowledge about DET careers. An associated barrier seems to be a lack of resources and training available to them. 
Table 3. Barriers to Advising Students about DET Careers - Code Themes and Examples (Item 21, N = 49)

\begin{tabular}{|l|c|l|}
\hline Codes Theme & $\begin{array}{c}\text { Number of } \\
\text { Responses }\end{array}$ & Example \\
\hline Lack of Knowledge & 25 & $\begin{array}{l}\text { Mainly the lack of overall knowledge in the field and what } \\
\text { kinds of jobs are available for someone with this degree. }\end{array}$ \\
\hline Lack of Time & 18 & Limited time to spend with students. \\
\hline $\begin{array}{l}\text { Misconceptions } \\
\text { (parents/students) }\end{array}$ & 2 & $\begin{array}{l}\text { Difficulty overcoming misconceptions that students \& } \\
\text { parents have regarding DET careers. }\end{array}$ \\
\hline Offered courses for students & 2 & $\begin{array}{l}\text { Due to our small, rural area, we are not able to offer more } \\
\text { elective courses geared toward DET that could help students } \\
\text { (besides the math and sciences). }\end{array}$ \\
\hline $\begin{array}{l}\text { Students having adequate } \\
\text { skills }\end{array}$ & $\begin{array}{l}\text { Students who want engineering fields but do not have the } \\
\text { grades to formally pursue careers in this field. Not sure if } \\
\text { the students are unaware of the skills needed for strong } \\
\text { engineering programs/careers }\end{array}$ \\
\hline
\end{tabular}

Table 4. Other Known Barriers to Advising Students About DET Careers - Code Themes and Examples (Item 22, $\mathrm{N}=28$ ).

\begin{tabular}{|l|c|l|}
\hline Code Theme & $\begin{array}{c}\text { Number of } \\
\text { Responses }\end{array}$ & Example \\
\hline Student Knowledge & 8 & $\begin{array}{l}\text { Students may not indicate interest because of lack of } \\
\text { familiarity with the field - few experiences. }\end{array}$ \\
\hline Knowledge & 5 & $\begin{array}{l}\text { Lack of knowledge about DET careers and the educational } \\
\text { requirements. }\end{array}$ \\
\hline Resources & 4 & $\begin{array}{l}\text { Our College and Career Resource person is part time and } \\
\text { paid secretarial pay-no benefits, no required degree, and not } \\
\text { full time. }\end{array}$ \\
\hline Role Model & 3 & $\begin{array}{l}\text { The lack of role models that they know in this field. } \\
\text { Student Preparation \& } \\
\text { Resources }\end{array}$ \\
\hline Time & 2 & $\begin{array}{l}\text { Some schools may not have the funds to offer such classes } \\
\text { and many students are clueless about the DET career } \\
\text { options. }\end{array}$ \\
\hline Counselor to student ratios - we have too many students. \\
\hline Academic Honors & 1 & $\begin{array}{l}\text { The great push for Academic Honor Diplomas and need to } \\
\text { cut cost, the hands on classes in the career and Technical } \\
\text { areas have been cut. }\end{array}$ \\
\hline Misconceptions & 1 & Student misconceptions about engineering majors as people. \\
\hline Curriculum & 1 & $\begin{array}{l}\text { Lack of engineering-friendly curriculum at lower grade } \\
\text { levels. }\end{array}$ \\
\hline
\end{tabular}

One reported barrier that is surprising, and emerged through the open-ended responses to questions 21 and 22, is students' (and parents') lack of knowledge. The nature of this barrier is somewhat unclear, but almost seems to indicate that students (and parents) must obtain some threshold knowledge of or interest in engineering to facilitate counseling about DET careers.

In Table 5, the school counselors responses to the barrier items (Items 16-21) are parsed according to the counselors responses to the items regarding preparation to advise students about DET careers (Item 13), adequacy of advising students interested in DET careers, and a feeling of doing all they should to advise students about DET careers. The body of the table contains counts of school counselors that agreed or strongly agreed with the barrier items (Items 
16-20) or provided coded responses within the coded themes of lack of time or lack of knowledge (Item 21). Not surprisingly, a high percentage of the school counselors that expressed being unprepared to advise students, inadequately advising students interested in DET careers, or not doing all they should to advise students agreed or strongly agreed that all of the barriers listed (except administration support) are barriers (78.6-100\%, Items 16-19). In contrast, school counselors that expressed being prepared being prepared to advise students, adequately advising students interested in DET careers, or doing all they should to advise students agreed or strongly agreed less often that all the barriers listed are barriers. The percent of agree and strongly agree responses for items 16-19 dropped to 29.2-70.6\%. Lack of knowledge about DET showed the greatest decline in agree and strongly agree responses.

Table 5. Correlations between Self-reported Barriers to Advising Students about Engineering Careers

\begin{tabular}{|c|c|c|c|c|c|c|c|}
\hline \multirow[t]{2}{*}{$\begin{array}{l}\text { Item } \\
\text { No. }\end{array}$} & \multirow{2}{*}{$\begin{array}{l}\text { Statement } \\
\text { (Number of Agree or } \\
\text { Strongly Agree } \\
\text { Responses or Coded } \\
\text { Responses within the } \\
\text { Theme) }\end{array}$} & \multicolumn{2}{|c|}{$\begin{array}{l}\text { 13. I am prepared to } \\
\text { advise my students } \\
\text { about DET careers. }\end{array}$} & \multicolumn{2}{|c|}{$\begin{array}{l}\text { 14. I adequately } \\
\text { advise all my students } \\
\text { interested in DET } \\
\text { careers. } \\
\end{array}$} & \multicolumn{2}{|c|}{$\begin{array}{l}\text { 15. I am not doing al } \\
\text { that I should be in } \\
\text { advising my students } \\
\text { about DET careers. }\end{array}$} \\
\hline & & $\begin{array}{l}\text { Disagree / } \\
\text { Strongly } \\
\text { Disagree } \\
(\mathrm{N}=18) \\
\end{array}$ & $\begin{array}{l}\text { Agree / } \\
\text { Strongly } \\
\text { Agree } \\
(\mathrm{N}=34) \\
\end{array}$ & $\begin{array}{c}\text { Disagree / } \\
\text { Strongly } \\
\text { Disagree } \\
(\mathrm{N}=24) \\
\end{array}$ & $\begin{array}{l}\text { Agree / } \\
\text { Strongly } \\
\text { Agree } \\
(\mathrm{N}=27) \\
\end{array}$ & $\begin{array}{l}\text { Disagree / } \\
\text { Strongly } \\
\text { Disagree } \\
(\mathrm{N}=24) \\
\end{array}$ & $\begin{array}{c}\text { Agree / } \\
\text { Strongly } \\
\text { Agree } \\
(\mathrm{N}=28) \\
\end{array}$ \\
\hline 16 & $\begin{array}{l}\text { The limited time for } \\
\text { counselors to learn about } \\
\text { DET acts as a barrier for } \\
\text { advising students about } \\
\text { DET careers. }\end{array}$ & $\begin{array}{c}17 \\
(94.4 \%)\end{array}$ & $\begin{array}{c}24 \\
(70.6 \%)\end{array}$ & $\begin{array}{c}24 \\
(100 \%)\end{array}$ & $\begin{array}{c}16 \\
(59.3 \%)\end{array}$ & $\begin{array}{c}14 \\
(58.3 \%)\end{array}$ & $\begin{array}{c}28 \\
(100 \%)\end{array}$ \\
\hline 17 & $\begin{array}{l}\text { The limited time available } \\
\text { to advise students about } \\
\text { DET careers acts as a } \\
\text { barrier for advising } \\
\text { students about DET } \\
\text { careers. }\end{array}$ & $\begin{array}{c}16 \\
(88.8 \%)\end{array}$ & $\begin{array}{c}22 \\
(64.5 \%)\end{array}$ & $\begin{array}{c}20 \\
(83.3 \%)\end{array}$ & $\begin{array}{c}17 \\
(63.0 \%)\end{array}$ & $\begin{array}{c}12 \\
(50.0 \%)\end{array}$ & $\begin{array}{c}26 \\
(92.9 \%)\end{array}$ \\
\hline 18 & $\begin{array}{l}\text { My lack of knowledge } \\
\text { about DET careers acts as } \\
\text { a barrier for advising } \\
\text { students about DET } \\
\text { careers. }\end{array}$ & $\begin{array}{c}16 \\
(88.8 \%)\end{array}$ & $\begin{array}{c}13 \\
(38.2 \%)\end{array}$ & $\begin{array}{c}21 \\
(87.5 \%)\end{array}$ & $\begin{array}{c}7 \\
(25.9 \%)\end{array}$ & $\begin{array}{c}7 \\
(29.2 \%)\end{array}$ & $\begin{array}{c}22 \\
(78.6 \%)\end{array}$ \\
\hline 19 & $\begin{array}{l}\text { The lack of available } \\
\text { training acts as a barrier } \\
\text { for advising students } \\
\text { about DET careers. }\end{array}$ & $\begin{array}{c}15 \\
(83.3 \%)\end{array}$ & $\begin{array}{c}18 \\
(52.9 \%)\end{array}$ & $\begin{array}{c}19 \\
(79.2 \%)\end{array}$ & $\begin{array}{c}13 \\
(48.1 \%)\end{array}$ & $\begin{array}{c}11 \\
(45.8 \%)\end{array}$ & $\begin{array}{c}22 \\
(78.6 \%)\end{array}$ \\
\hline 20 & $\begin{array}{l}\text { The lack of administration } \\
\text { support acts as a barrier } \\
\text { for advising students } \\
\text { about DET careers. }\end{array}$ & $\begin{array}{c}3 \\
(16.7 \%)\end{array}$ & $\begin{array}{c}8 \\
(23.6 \%)\end{array}$ & $\begin{array}{c}6 \\
(25.0 \%)\end{array}$ & $\begin{array}{c}5 \\
(18.5 \%)\end{array}$ & $\begin{array}{c}5 \\
(20.8 \%)\end{array}$ & $\begin{array}{c}6 \\
(21.4 \%)\end{array}$ \\
\hline & & $(\mathrm{N}=17)$ & $(\mathrm{N}=24)$ & $(\mathrm{N}=22)$ & $(\mathrm{N}=18)$ & $(\mathrm{N}=17)$ & $(\mathrm{N}=20)$ \\
\hline 21 & $\begin{array}{l}\text { Code Theme - Lack of } \\
\text { Knowledge }\end{array}$ & $\begin{array}{c}6 \\
(35.3 \%) \\
\end{array}$ & $\begin{array}{c}20 \\
(83.3 \%) \\
\end{array}$ & $\begin{array}{c}18 \\
(81.8 \%) \\
\end{array}$ & $\begin{array}{c}7 \\
(38.9 \%) \\
\end{array}$ & $\begin{array}{c}12 \\
(70.6 \%) \\
\end{array}$ & $\begin{array}{c}11 \\
(55 \%) \\
\end{array}$ \\
\hline 21 & $\begin{array}{l}\text { Code Theme - Lack of } \\
\text { Time }\end{array}$ & $\begin{array}{c}7 \\
(41.2 \%) \\
\end{array}$ & $\begin{array}{c}11 \\
(45.8 \%)\end{array}$ & $\begin{array}{c}9 \\
(40.9 \%)\end{array}$ & $\begin{array}{c}9 \\
(50.0 \%)\end{array}$ & $\begin{array}{c}5 \\
(29.4 \%)\end{array}$ & $\begin{array}{c}12 \\
(60.0 \%)\end{array}$ \\
\hline
\end{tabular}




\section{Topics School Counselors would like to Advise their Students about Engineering}

Table 6 shows the results for items 23-26. School counselors revealed the desire to have more resources and information about all areas listed which include: high school courses that prepare students for careers in engineering (Item 23), which careers use STEM skills (Item 24), opportunities available to support them through the educational engineering pathway (Item 25), and scholarships (Item 26).

Table 6. Topics School Counselors Would Like to Advise Their Students About Engineering.

\begin{tabular}{|l|l|c|c|c|c|c|}
\hline $\begin{array}{l}\text { Item } \\
\text { No. }\end{array}$ & $\begin{array}{l}\text { Statement } \\
\text { (Number of Responses) }\end{array}$ & $\begin{array}{l}\text { Strongly } \\
\text { Disagree }\end{array}$ & Disagree & Agree & $\begin{array}{c}\text { Strongly } \\
\text { Agree }\end{array}$ & $\begin{array}{c}\text { Average/ } \\
\text { Median }\end{array}$ \\
\hline With regards to engineering careers, I would like to be able to advise my students about ... \\
\hline 23 & $\begin{array}{l}\text { What high school courses } \\
\text { prepare them for careers in } \\
\text { engineering? (n=52) }\end{array}$ & $0 \%(0)$ & $0 \%(0)$ & $42.3 \%(22)$ & $57.7 \%(30)$ & $3.6 / 4$ \\
\hline 24 & $\begin{array}{l}\text { Which careers use STEM skills. } \\
\text { (n=50) }\end{array}$ & $0 \%(0)$ & $0 \%(0)$ & $52.0 \%(26)$ & $48.0 \%(24)$ & $3.5 / 3$ \\
\hline 25 & $\begin{array}{l}\text { Opportunities available to } \\
\text { support them through the } \\
\text { educational engineering } \\
\text { pathway. (n=52) }\end{array}$ & $0 \%(0)$ & $5.8 \%(3)$ & $36.5 \%(19)$ & $57.7 \%(30)$ & $3.5 / 4$ \\
\hline 26 & $\begin{array}{l}\text { Available scholarships for } \\
\text { entering college in engineering } \\
\text { studies. (n=52) }\end{array}$ & $0 \%(0)$ & $7.7 \%(4)$ & $25.0 \%(13)$ & $67.3 \%(35)$ & $3.6 / 4$ \\
\hline
\end{tabular}

Question 44 asked, "What resources do you need, but do not have available to you, to advise students about engineering careers?" Table 7 shows the categories and frequency of requested items. These responses reveal the desired types of information wanted by school counselors. The most requested types of resources needed were pamphlets and guest speakers for students.

Table 7. Resources Needed for Advising Students about Engineering Careers (Item 44, $\mathbf{N}=38$ ).

\begin{tabular}{|l|c|}
\hline Categories & $\begin{array}{c}\text { Number of } \\
\text { Requests }\end{array}$ \\
\hline Pamphlets & 23 \\
\hline Guest Speakers for Students & 17 \\
\hline Websites & 14 \\
\hline Presentations & 10 \\
\hline Hands-on- activities & 7 \\
\hline Videos & 2 \\
\hline Total & 73 \\
\hline
\end{tabular}

The majority of the resources requested are readily available. It would seem that counselors' busy schedules may prevent them from accessing and using these resources effectively. The results reveal the need for a better system for counselors to gain access to the resources engineering colleges/universities provide about their programs. 


\section{Desired Time and Location of Workshops}

Table 8 shows the results for items $27-34$. Due to the school counselors' hectic and challenging schedules, the time and location of an advertised workshop must be carefully selected. When presented with typical options for the time and location of a professional development workshop, the majority of the responses were split between agree and disagree, except for two options. The two options that appear to be most promising are to offer a workshop during a session at the Indiana School Counselor Association (ISCA) conference (80.4\% agree or strongly agree, Item 27 ). This preference may reflect the survey participants' level of participation in ISCA. The data reveal that workshops scheduled during the summer (Item 30), afterschool (Item 31), or on a Saturday (Item 32) are less likely to be attended. This information paired with the listed barriers reveal that professional development workshops need to be short, offered in a convenient location, and show direct application to their job duties.

Table 8. Desired Time and Location of Workshops.

\begin{tabular}{|l|l|c|c|c|c|c|}
\hline $\begin{array}{l}\text { Item } \\
\text { No. }\end{array}$ & $\begin{array}{l}\text { Statement } \\
\text { (Number of Responses) }\end{array}$ & $\begin{array}{l}\text { Strongly } \\
\text { Disagree }\end{array}$ & Disagree & Agree & $\begin{array}{c}\text { Strongly } \\
\text { Agree }\end{array}$ & $\begin{array}{c}\text { Average/ } \\
\text { Median }\end{array}$ \\
\hline I am interested in learning more about engineering careers through... & \multicolumn{3}{|l|}{} \\
\hline 27 & $\begin{array}{l}\text { workshop at Indiana School } \\
\text { Counselor Association (ISCA). } \\
\text { (n=52) }\end{array}$ & $5.8 \%(3)$ & $13.5 \%(7)$ & $65.4 \%(34)$ & $15.4 \%(8)$ & $2.9 / 3$ \\
\hline 28 & $\begin{array}{l}\text { workshop at Indiana Counseling } \\
\text { Association Conference (ICA). } \\
\text { (n=52) }\end{array}$ & $11.5 \%(6)$ & $44.2 \%(23)$ & $40.4 \%(22)$ & $3.8 \%(2)$ & $2.4 / 2$ \\
\hline 29 & school in-service. (n=50) & $10.0 \%(5)$ & $30.0 \%(15)$ & $44.0 \%(22)$ & $16.0 \%(8)$ & $2.6 / 3$ \\
\hline 30 & summer course. (n=51) & $7.8 \%(4)$ & $51.0 \%(26)$ & $35.3 \%(18)$ & $5 / 9 \%(3)$ & $2.4 / 2$ \\
\hline 31 & workshop after school. (n=51) & $5.9 \%(3)$ & $45.1 \%(23)$ & $43.1 \%(22)$ & $5 / 9 \%(3)$ & $2.5 / 2$ \\
\hline 32 & workshop on a Saturday. (n= 49) & $12.2 \%(6)$ & $59.2 \%(29)$ & $24.5 \%(12)$ & $4.1 \%(2)$ & $2.2 / 2$ \\
\hline 33 & $\begin{array}{l}\text { workshop located within an } \\
\text { hour's driving distance. (n=48) }\end{array}$ & $4.2 \%(2)$ & $27.1 \%(13)$ & $47.9 \%(23)$ & $20.8 \%(10)$ & $2.9 / 3$ \\
\hline 34 & online course. (n=50) & $16.0 \%(8)$ & $28.0 \%(14)$ & $50.0 \%(25)$ & $6.0 \%(3)$ & $2.5 / 3$ \\
\hline
\end{tabular}

\section{E. Perceptions about Collaborating with other Teachers on Engineering Lessons}

Results for items 36-41 (Table 9) reveal that school counselors tend to agree that they are interested in collaborating with teachers on engineering lessons, and they feel that teachers would also be interested in such collaboration. 
Table 9. School Counselors' Perceptions about Collaborating with other Teachers on Engineering Lessons

\begin{tabular}{|l|l|c|c|c|c|c|}
\hline $\begin{array}{l}\text { Item } \\
\text { No. }\end{array}$ & $\begin{array}{l}\text { Statement } \\
\text { Number of Responses) }\end{array}$ & $\begin{array}{c}\text { Strongly } \\
\text { Disagree }\end{array}$ & Disagree & Agree & $\begin{array}{c}\text { Strongly } \\
\text { Agree }\end{array}$ & $\begin{array}{c}\text { Average } \\
\text { /Median }\end{array}$ \\
\hline I am interested in collaborating on an engineering lesson with the following teachers. \\
\hline 36 & $\begin{array}{l}\text { Science Educators } \\
(\mathrm{n}=51)\end{array}$ & $7.8 \%(4)$ & $23.5 \%(12)$ & $62.7 \%(32)$ & $5.9 \%(3)$ & $2.7 / 3$ \\
\hline 37 & Mathematics Educators ( $=51)$ & $7.8 \%(4)$ & $23.5 \%(12)$ & $62.7 \%(32)$ & $5.9 \%(3)$ & $2.7 / 3$ \\
\hline 38 & $\begin{array}{l}\text { Technology Educators } \\
(\mathrm{n}=51)\end{array}$ & $7.8 \%(4)$ & $21.6 \%(11)$ & $60.8 \%(31)$ & $9.9 \%(5)$ & $2.7 / 3$ \\
\hline $\begin{array}{l}\text { How interested in collaborating on an engineering career lesson do you perceive the following teachers to } \\
\text { be? }\end{array}$ \\
\hline 39 & $\begin{array}{l}\text { Science Educators } \\
(\mathrm{n}=50)\end{array}$ & $2.0 \%(1)$ & $22.0 \%(11)$ & $60.0 \%(30)$ & $16.0 \%(8)$ & $2.9 / 3$ \\
\hline 40 & Mathematics Educators (n= 51) & $4.0 \%(2)$ & $26.0 \%(13)$ & $56.0 \%(28)$ & $14.0 \%(7)$ & $2.8 / 3$ \\
\hline 41 & $\begin{array}{l}\text { Technology Educators } \\
(\mathrm{n}=51)\end{array}$ & $4.0 \%(2)$ & $20.0 \%(10)$ & $52.0 \%(26)$ & $24.0 \%(12)$ & $3.0 / 3$ \\
\hline
\end{tabular}

The data reveals a difficult situation. Sixty-five percent of the school counselors participating in this survey confirm they are prepared to advise their students on DET, yet $38.2 \%$ acknowledge that a lack of knowledge acts as a barrier when advising students about DET careers. Sixty-four percent of school counselors agree or strongly agree that there is a lack of available training, yet there is little agreement on the time and location for professional development, possibly due to the expressed lack of time for training and advising of students. In addition, some responses conveyed a negative attitude towards engineering professional development. This can be seen in the following statement, "Please create a counselor training that is specific to counselors. I don't want to know everything in the world about engineering if I did I would have become one."

\section{Implications}

The engineering community needs to share with school counselors why we are interested working with them to better advise students about DET careers. We must show them the need, usefulness, benefit, and impact professional development can have on their students' futures. However, to get them to attend a professional development session outside of the regular workday may be a challenge; therefore, the training needs to be sensitive to school counselors' schedules and limited knowledge.

Overall, there needs to be a better system for school counselors to access the information and resources they need. The resources requested by the school counselors are provided by many engineering colleges but they do not seem to have the time to access them or become familiar with them. Materials need to be designed that are user friendly, easy to access, and readily available. Professional development trainings need to be short and to the point, while hitting on a few main topics that school counselors will find relevant.

While an online course (Item 34) was the most popular amongst the time and location options for professional development, online professional development scenarios may still be a choice 
with the most impact. The school counselor can pick which units best fits their needs/desires. In a sense, the school counselor can customize the professional development unit to meet their specific community needs. It is available when they have the time and on their terms. In addition, the products developed could be used by more than one audience such as students, parents, or even teachers.

\section{Limitations of the Pilot Study}

Limitations of this pilot study included the lack of participants' demographic data such as gender, population size, participants' access and comfort level with computers as related to the survey being conducted online, and the self-reporting nature of the questions. The lack of demographic data and population size does not allow us to see if there are patterns in the responses that are influenced by community, gender, or age. Participation in this study was limited to those who have computers, internet access, and access to the Counselortalk list-serv. This limits the generalizabity of the results. The nature of the questions may lead respondents to provide answers that they believe the researchers expect rather than what they truly believe. This may strain the validity of the results; since, people's feelings are hard to place in agree/disagree categories. Lastly, the online nature of the survey may have required more thorough instructions for the respondents to understand the survey. This additional instruction was not possible due to the survey being administered through email instead of in person. However, respondents may feel more comfortable answering questions through an online survey than on a paper-based survey.

\section{Conclusions and Future Research Directions}

This was a pilot study of school counselors' perceptions of both engineering and their advising of students about DET. It was found that school counselors have similar beliefs about DET as teachers. Lack of time and knowledge present are seemingly significant barriers to school counselors advising students about DET careers. From these results, lack of time for learning about DET seems to limit times and locations for professional development. Curiously, school counselors listed a need for resources that are readily available, perhaps another indication of the impact of lack of time for learning about DET and advising.

A number of future research directions have emerged from this work.

1. There is a need to better understand the work of school counselors - what they are doing to advise students about DET education and careers and what they are willing and able to do in this regard. Research in this area is particularly needed as it is believed that counselors have the opportunity to identify future engineers that are currently not being encouraged to enter an engineering pathway. So one question is, "Do they have and/or act on this opportunity, and if so, how?" A related question is "To what extent do school counselors rely on students and parents to be informed about engineering and express an interest in engineering to start having the conversation about DET careers?"

2. There is a need to better understand school counselors' perceptions and knowledge of engineering and their perceptions of their students' and students' parents' perceptions and knowledge of engineering. Such understandings would inform the development of appropriate professional development materials for all three populations. 
3. Different models for delivering professional development should be investigated for impact. For instance, a comparison could be made between a workshop held during an ISCA conference versus an online workshop.

It is clear that the engineering community needs to learn about the roles and training of school counselors and their experiences in advising with DET so that we can productively work them to educate students about engineering. We must be sensitive to their strong feelings of a lack of time available to learn and advise students about DET and develop clear goals for advising students about DET that align to their roles and responsibilities.

\section{Bibliography}

1. Parsad, B., Alexander, D., Farris, E., \& Hudson, L. (2004) High School Guidance Counseling. Education Statistics Quarterly. Vol 5(3) 49-53.

2. Noeth, R.J., Cruce, T., \& Harmston, M. (2003) Maintaining a strong engineering workforce. ACT Policy Report, ACT, inc Iowa city, IA

3. National Science Board. (2003). The science and engineering workforce/ realizing America's potential, 2003. Washington, DC: US Government Printing Office.

4. Gonzales, P., Williams, T., Jocelyn, L., Roey, S., Kastberg, D., and Brenwald, S. (2008). Highlights From TIMSS 2007: Mathematics and Science Achievement of U.S. Fourth-and Eighth-Grade Students in an International Context (NCES 2009-001).National Center for Education Statistics, Institute of Education Sciences, U.S. Department of Education. Washington, DC.

5. Gonzales P., Guzmán C., Partelow, L., Pahlke,E., Jocelyn,L., Kastberg, D., and Williams, T. (2004). Highlights From the Trends in International Mathematics and Science Study (TIMSS) 2003 (NCES 2005-005). U.S. Department of Education, National Center for Education Statistics. Washington, DC: U.S. Government Printing Office.

6. National Center for Educational Statistics. (2007). 2007 Math Nations Report Card. Retrieved May 5, 2008, from http://nces.ed.gov/pubsearch.

7. National Center for Educational Statistics. (2005). 2005 Science Nations Report Card. Retrieved May 5, 2008, from http://nces.ed.gov/pubsearch.

8. National Science Board, Science and Engineering Indicators, 1993, Washington, D.C.: U.S. Government Printing Office, 1993.

9. National Science Board, Science and Engineering Indicators, 2004, Arlington, VA: National Science Foundation (NSB 04-1), 2004.

10. National Science Board, Science and Engineering Indicators, 2006, Arlington, VA: National Science Foundation (NSB 06-01), 2006.

11. National Academy of Sciences, Rising Above the Gathering Storm: Energizing and Employing America for a Brighter Economic Future, Washington D.C: National Academies Press, 2007.

12. Douglas, J., Iverson, E., \& Kalyandurg, C., (2004) "Engineering in the K-12 Classroom: An Analysis of Current Practices \& Guidelines for the Future," ASEE Engineering K-12 Center. Washington, D.C.

13. Hoyt, K. \& Hughey, K. (1997) Career Counseling in the knowledge age: Implications for change in school counselor education programs. Journal of Career Development 24(2) 95-102. 
14. Partin, R. (1990) School Counselor's time: A Comparison of counselors' and principals' perceptions and desires. Paper presented at the annual meeting of the American association for counseling and development (Cincinnati, Ohio).

15. Creswell, J. (2002). Educational research: Planning, conducting, and evaluating quantitative and qualitative research. Upper Saddle River, NJ: Merrill/Prentice Hall.

16. Yasar, S., Baker, D., Robinson-Kurpius, S., Krause, S., \& Roberts, C. (2006). Development of a survey to assess K-12 teachers' perceptions of engineers and familiarity with teaching design, engineering, and technology. Journal of Engineering Education, 95 (3), 205-216.

17. Strauss, A. \& Corbin, J. (1998). Basics of qualitative research: Techniques and procedures for developing grounded theory. ( $2^{\text {nd }}$ ed.). Thousand Oaks, CA: Sage. 